Hembree, Wright 2008; Shrestha et al. 2010). The level of glyphosate resistance in horseweed is relatively low, and resistant plants are usually injured to some degree following glyphosate applications, which suggests that resistance is not due to an altered target enzyme. Genetic comparisons of horseweed accessions from around the state suggest that there have been multiple, independent origins of resistance in this species, rather than the spread of resistance from a single-source population (Okada et al. 2013).

Hairy fleabane (Conyza bonariensis) populations resistant to glyphosate were reported in 2007 (Shrestha, Hanson,
Hembree 2008). Glyphosate resistance in hairy fleabane appears to be similar to resistance in horseweed in that (1) selection has occurred in response to similar management strategies in perennial crops and surrounding areas (Hembree and Shrestha 2007); (2) multiple origins of resistance are suspected (Okada et el. 2014); and (3) growth stage and environmental conditions affect the level of resistance (Moretti, Hanson et al. 2013; Shrestha et al. 2007). The discovery by Moretti, Hanson et al. (2013) of hairy fleabane resistant to both glyphosate and paraquat raises questions about whether a common physiological mechanism is helping to confer resistance to these dissimilar herbicides, and research is ongoing to elucidate these factors.

Junglerice (Echinochloa colona) resistant to glyphosate was first identified in 2008 in a Roundup Ready corn field in the Sacramento Valley (Alarcon-Reverte et al. 2013); since then, glyphosate-resistant junglerice has become widespread in orchards and field crops throughout California (Moretti, Garcia et al. 2013). Resistance appears to be due to mutations in the EPSPS target site (Alarcon-Reverte et al. 2013), although some populations also appear to have enhanced EPSPS activity (A.J. Fischer, unpublished data).

\title{
Herbicide-resistant weeds unlikely in vegetable crops
}

\section{by Steve Fennimore, Richard Smith and Michelle Le Strange}

W eed management systems in California vegetable crops can be described as robust, complex, multitactic and integrated. Vegetable herbicides generally make up just one component in a multicomponent weed management system. With California's seasonally dry weather and growers' ability to control soil moisture by means of irrigation scheduling, it becomes possible for the grower to apply effective cultural and physical control practices, such as preparation of stale seedbeds and inter-row cultivation. Redundancy is designed into the weed management system to minimize weed emergence in the crop. The key tools that make up an integrated vegetable weed management system are field selection, sanitation, crop rotation, land preparation, stale seedbeds, herbicides and physical weed control (UC IPM 2009). Growers who carefully apply these practices are able to manage weeds effectively and reduce the presence of weed seeds in the soil seedbank.

Field selection. Farmers often grow vegetable crops on fields that have low weed pressure so their weed control operations can be more efficient and economical. They use translocated herbicides during fallow periods to control troublesome perennial weeds like field bindweed.

Sanitation. Growers often keep vegetable fields and the surrounding areas as weed-free as possible to keep the weeds from going to seed. Some operations that utilize a "zero weed seed" philosophy have successfully reduced weed pressure in subsequent vegetable crops by eliminating weed seed inputs to the soil seedbank. Other measures such as cleaning all field equipment when moving it from a weedy field or into a clean field are also employed.

Rotation. By growing vegetable crops in rotation with crops that normally have more intensive weed control programs, growers can help keep a field clean of weeds. Because field conditions are constantly changing under a rotation system, no one weed species is likely to become dominant.

Land preparation. Direct-seeded vegetable crops require wellprepared seedbeds free of large clods to facilitate precision planting and allow rapid and uniform emergence of vegetable seedlings. A uniform seeding depth is critical to uniform crop emergence and improved tolerance to herbicides. Mechanical cultivation is facilitated with smooth seedbeds and good tilth, which allows the cultivation equipment to remove weeds that are close to the crop row. Increasingly, growers are using precision guidance systems to improve the speed and accuracy of cultivation.

Preirrigation and use of a stale seedbed. Preirrigation before final seedbed preparation is a common practice, as it stimulates a weed flush a few days after watering. As soon as the weeds have emerged and the field is dry enough to enter, the grower uses shallow cultivation, flaming or a nonselective herbicide to remove the new weeds. Research has shown this technique to provide $15 \%$ to $50 \%$ control of weeds in crops like lettuce (Shem Tov et al. 2006). The combination of stale seedbed technique and both herbicides and cultivation often results in good weed control.

Herbicides. One category of herbicide used in vegetable crops is fumigants, such as metam potassium, which is applied 14 to 21 days before planting to kill weed seeds and germinating seedlings. After planting, soil-active herbicides like pronamide (used in artichokes and head lettuce) and S-metolachlor and trifluralin (used in tomatoes and peppers) are applied to provide preemergence control of weeds. Postemergence herbicides are utilized in some crops; examples include clethodim, used to control emerged grass weeds in many broadleaf vegetable crops, and oxyfluorfen and bromoxynil, used to control broadleaf weeds. Many vegetable herbicides were developed in the 1960s and 1970s and include products like DCPA (used in broccoli and onion), napropamide (used in tomatoes and peppers) and linuron (used in asparagus and celery). Given the complexity of the vegetable weed control program and the extensive use of cultivation and hand-weeding, the selective pressure on weeds from vegetable herbicides is very light, despite their decades of use.

Physical weed control. Vegetable growers make extensive use of physical weed control. One example is inter-row cultivation or shallow cultivation between the crop rows to control weeds. Interrow cultivation is a very old but effective method that buries, cuts or uproots weeds. Hand-weeding by workers with hoes is the last 
Target-site mutations appear to be the most frequent mechanism among the accessions so far collected in California; however, additional research is ongoing to determine whether the same is true with populations selected in orchards and in other regions of the Central Valley.

Several other common weeds in orchards and vineyards, including Palmer amaranth (Amaranthus palmeri), threespike goosegrass (Eleusine tristachya) and witchgrass (Panicum capillare), are suspected to have evolved resistance to glyphosate; preliminary research trials by UC researchers and California State University, Fresno, collaborators have been initiated to verify and characterize the putative resistant populations.

\section{California herbicide resistance research: Locally applied research and exten- sion with national and international implications}

Since the discovery of herbicideresistant weed biotypes in California, UC research and Cooperative Extension personnel, as well as university and nonuniversity cooperators and students, have conducted locally relevant weed management research in the state. Research and extension efforts have included alternative chemical management techniques using various postemergence and preemergence herbicides along with mechanical control measures in an integrated approach. Applied research integrating agronomy, weed control, spray application technology and water management have been useful to regulatory agencies (e.g., California Department of Pesticide Regulation and California Environmental Protection Agency) and have had positive impacts on water and air quality, wildlife habitat and water use (Pittelkow et al. 2012).

Information on the underlying mechanisms and genetic basis of resistance provides useful information to California line of defense against weeds in vegetable crops. Among the hoeing crew, manual dexterity and good depth perception allow the workers to carefully remove weeds from the vegetable crop in the row and near the crop plant. Hand-weeding is expensive and can cost $\$ 300$ or more per acre in organic vegetable plantings and highdensity plantings (e.g., spinach and baby lettuces) — sometimes a lot more.

Integrated weed management in lettuce. In a typical lettuce weed control program, the crop is grown on a field with a light weed population, so one tool growers use is field selection. Sometimes the soil is fumigated with metam potassium before planting to control weeds and soilborne diseases, but most lettuce is grown on nonfumigated land. Prior to planting, the soil is irrigated to stimulate weed emergence and then shallow-tilled to kill weeds and form a smooth seedbed for planting. At time of seeding, preemergence herbicides such as pronamide or bensulide are applied, to be activated with the initial sprinkler irrigation. About 4 weeks after emergence, the lettuce is hand-thinned and weeded by a hoeing crew to its final stand. Inter-row cultivation in furrows and on bed tops is conducted one or more times, also removing weeds. Finally, about 6 weeks after lettuce emergence, the field is hand-weeded to remove any remaining weeds. After harvest, the field is quickly tilled under, killing any remaining weeds before the field is rotated to another crop.

Integrated weed management in tomatoes. Virtually all California tomatoes are transplanted, and $75 \%$ are grown using subsurface drip irrigation buried 8 to 10 inches deep. Fields with low weed populations, especially those free of field bindweed and dodder, are most often sought for tomato production. Beds are preirrigated to germinate weeds, then cultivated and shaped prior to planting. Typically only two herbicide applications are made: one just prior to planting or at planting, and the other at layby. Herbicides such as halosulfuron, pendimethalin, rimsulfuron, S-metolachlor, sulfentrazone and trifluralin are used, depending upon the site and weed spectrum. Just prior to layby application, beds and furrows are mechanically cultivated.

These practices significantly reduce weed emergence and competition against the young tomato crop. Hoeing crews may handweed once or twice before or after layby, depending on weed populations. Adding to the cost for growers who practice "zero weed seed tolerance" is the physical removal of troublesome weeds such as flowering nightshades and dodder to prevent seeding and further field contamination. The harvest operation undercuts all plants growing on the bed top, and after harvest the field is quickly tilled under, killing any remaining weeds before the field is rotated to another crop.

The lettuce and tomato weed management systems are intensive and redundant, made up of many operations conducted in sequence with the aim of minimizing weed emergence. In practice, these weed management systems are not always as flawless as the above descriptions might suggest. Crops like broccoli and cauliflower are grown during winter months, when extended rain and wet field conditions prevent cultivation and hand-weeding. Other complications are high-density plantings such as those used for spinach, which limit the grower's ability to cultivate.

Overall, the chances are low that weeds will develop herbicide resistance in a vegetable crop planting. Technology is evolving that will allow intelligent robotic cultivators to remove weeds from the intra-row space without the use of herbicides, so there is reason for optimism that the development of herbicide-resistant weeds in California vegetable fields will remain low for the foreseeable future.

S. Fennimore is UC Cooperative Extension (UCCE) Specialist, Department of Plant Sciences, UC Davis; R. Smith is UCCE Farm Advisor, Monterey County; and M. Le Strange is UCCE Farm Advisor Emeritus, Tulare County.

\section{References}

Shem-Tov S, Fennimore SA, Lanini WT. 2006. Weed management in lettuce (Lactuca sativa) with pre-plant irrigation. Weed Technol 20:1058-65.

UC IPM. 2009. Integrated weed management. In: Spinach: UC IPM Pest Management Guidelines. UC ANR Pub 3467. Oakland, CA. www.ipm.ucdavis.edu/PMG/ r732700111.html. 